\title{
Exploration of the Integration of Individualization Learning Concept and Flipped Classroom Teaching Mode
}

\author{
Yanbo Liu, a and Binbin Yu, ${ }^{1, b^{*}}$ \\ ${ }^{1}$ Beihua University, College of Information Technology and Media, China \\ a283614335@qq.com, b22342690@qq.com \\ * please mark the corresponding author with an asterisk
}

\begin{abstract}
Keywords: Individualization learning; Flipped classroom; Micro video; Teaching design.
\end{abstract}
\begin{abstract}
The traditional teaching dominated by teachers has not been able to meet the needs of the learners, the new generation of teaching model represented by micro class, flipped classroom and mobile learning fully embodies the learners' subjectivity, autonomy and creativity. The immediacy of mobile learning is beneficial to stimulate learners' interest in learning and improve their learning initiative. In the flipped class, the task of the stage of imparting knowledge is completed by the students before class, and the task of knowledge internalization is accomplished by answering questions by teachers in class. The purpose of exploring the integration of individualized learning concept and flipped classroom is looking forward to improve the initiative, enthusiasm and creativity of learners, and ultimately optimize the teaching effect.
\end{abstract}

\section{Introduction}

The traditional teaching is mainly based on the teaching of teachers. Although it is beneficial to teachers' effective monitoring of teaching activities, ignore the learners' subjectivity, initiative. This is not conducive to learners' creativity. The essence of education is people-oriented, cultivating the talents needed by society. Individual differences such as learners' learning style should be respected, learners' individualized learning needs should be met. [1] In order to achieve the intended teaching objectives and optimize the teaching effect, teachers use a variety of teaching resources and teaching media to assist learners in meaningful learning in the process of learning. Integration of individualization learning concept and flipped classroom teaching mode can optimize teaching methods and promote learners' meaningful learning.

\section{Individualization Learning Overview}

The concept of individuation [2] has different definitions in different fields. individuation is one of the internal psychological, but the psychological demands of different learners are different. The learner's name, gender, religious belief, cultural level, world outlook, moral cultivation, educational background, cognitive level, cognitive motivation and economic level are different. [3]Some scholars in our country think that individualized teaching is that teachers fully respect the law of physical and mental development of learners, pay attention to the students' overall, coordinated and sustainable development. In the process of teaching, teachers use various teaching media and teaching resources to meet the needs of learners individualized learning and guide students to think independently and actively acquire knowledge and cultivate their ability to identify problems, ask questions and solve problems. [4]

Humanistic psychologists Maslow put forward the famous hierarchy of needs theory. He believes that people have some basic needs, including physiological needs, safety needs, love and being loved needs, respect for needs, the need for self-worth, thirst for knowledge needs and aesthetic needs. These requirements are arranged in a certain order. In the case that the next level needs to be satisfied, the needs of the upper level can be put forward, individual goals can be formed. [5] The hierarchy of needs theory is shown in Fig. 1. [6] In the process of teaching, teachers should take full account of different learners have different social and emotional needs and pay attention to the needs to have the characteristics of hierarchy. appropriate teaching strategies and methods should be choosed. Appropriate teaching media and teaching 
resources for teaching design should be used.Teachers can believe that learners have the ideal of self realization.

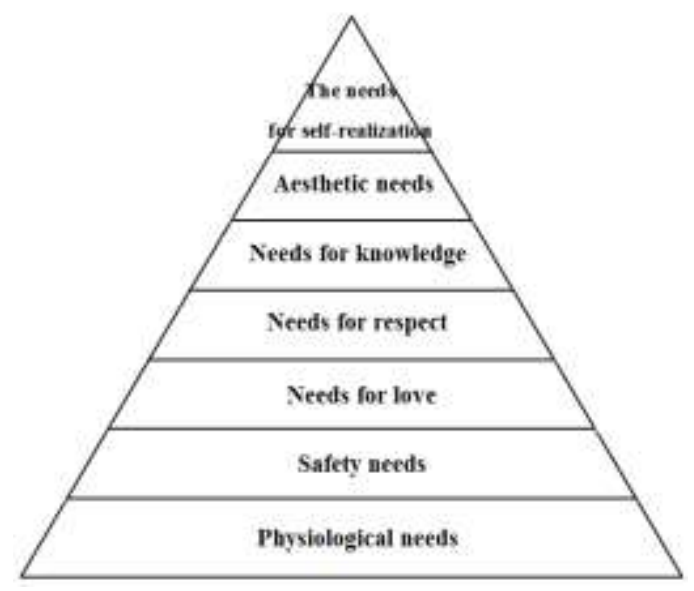

Figure 1. Finite The hierarchy of needs theory

\section{Individualized Learning Strategies}

Individualized Learning Strategy Based on Learning Style. Education is wisdom education, accurate education and individualized education and is the cultivation of talents in need of society. In today's society, with the development of science and technology, individualization learning has become one of the trends of education development. [7] Learning interest and cognitive motivation can stimulate and guide learners to conduct or maintain learning activities. The famous is the Folder-Silverman learning style theory [8], as shown in Table 1.

Table 1 Folder-Silverman learning style

\begin{tabular}{|c|l|}
\hline Learning styles & \multicolumn{1}{c|}{ Performance } \\
\hline Active - Contemplative & $\begin{array}{l}\text { Active learners like to discuss and answer questions; Contemplative } \\
\text { learners are willing to think about problems alone. }\end{array}$ \\
\hline Sensory - Intuitive & $\begin{array}{l}\text { Sensory learners pay attention to specific things; intuitive learners } \\
\text { pay more attention to abstract concepts. }\end{array}$ \\
\hline Visual - Verbal & $\begin{array}{l}\text { Learners with visual learning style focus on learning resources such } \\
\text { as pictures, charts and videos; Learners of verbal learning style pay } \\
\text { attention to reading texts and media type learning resources. }\end{array}$ \\
\hline Sequential - Integrated & $\begin{array}{l}\text { The sequential learners like to follow the steps and learn in a certain } \\
\text { order; The integrated learners like to synthesize, disperse and } \\
\text { survey the whole situation. }\end{array}$ \\
\hline
\end{tabular}

Learners' individual differences lead to their differences in learning conditions, cognitive styles, social and emotional needs. [9]In the process of teaching, teachers should fully consider the different needs of learners for social and emotional and use appropriate teaching methods, teaching strategies, teaching media in order to achieve better teaching quality. Individualized learning emphasizes "learners centered", whose purpose is to tap the learner's wisdom and maximize the learners' self-worth.

Individualized Learning Resources. Individualized learning resources should fit into the online learning environment, including text, audio and video and other enhanced multimedia resources. Teaching resources are designed according to the characteristics of learners themselves, the nature of subjects, teaching objectives, teaching contents and so on. In the process of teaching, teachers choose and analyze the teaching media, and design the teaching resources. [10] A variety of teaching resources are organically combined to assist teaching, which can give full play to the advantages of multimedia technology, in order to expect to get 
the desired teaching effect. Individualized learning resources with strong logic can characterize the practical significance. It helps learners effectively promote learners knowledge construction and meaningful learning.

\section{Theoretical Exploration of Individualized Learning Promoted by Flipped Classroom}

Micro Video Reshaping Education. Micro video [11] emphasizes learning in a very short period of time, and the loose knowledge and information unit is made into video, which greatly satisfies the individual learning needs of learners, and enriches the new way of learning knowledge for learners. Learners learn micro video using terminal devices such as mobile phones, tablet PCs, laptops and so forth. Learners select the learning content and monitor the learning process. It promotes learners' initiative and creativity, and promotes learners' all-round and sustainable development. The promotion of micro video teaching has received widespread attention and recognition. It occupies an increasingly important position in informal learning.

Design of Flipped Classroom Teaching Mode. The flipped classroom combines teacher leadership with learner centered principles, which enables teachers to better guide and inspire learners to learn. [12] The enthusiasm of learners' knowledge construction is mobilized, which is conducive to the cultivation of learners' autonomous learning and collaborative inquiry. Teachers design clear teaching activities according to the teaching objectives, the focus and difficulty of teaching.

Teaching Process Design. According to the teaching objectives, the teacher selects the appropriate teaching content and produces micro video with less than 10 minutes. Learners learning before class using the micro video learning resources provided by teacher. Once learners have problems, they can communicate with their classmates, and they can also consult the teacher to get personalized counseling. In class, teachers communicate with learners. They explore problems together. Teachers create individualized collaborative learning tasks according to different levels of learners' cognitive level so as to guide learners to brainstorm. Due to each learner's cognitive level is different, proper exercises are set up. It can promote learners' meaningful learning. After class, teachers arrange teaching tasks according to teaching objectives, diagnose and remedy students' after-school learning content.

\section{Summary}

In conclusion, the combination of personalized learning and flipped classroom can better reflect the essence of education, that is people-oriented. The flipped classroom emphasizes the learners' need for self realization based on the personalized learning theory, which can stimulate the learners' enthusiasm and promote the learners' self learning ability. It is beneficial to meet learners' different learning needs and personalized development.However, the practice of innovative flipped classroom is facing challenges, it needs deeper research to improve the teaching model.

\section{Acknowledgements}

This work is supported by the Science and Technology Research Project of Department of Education of Jilin Province (Grant 2016057).

\section{References}

[1] H.Y Wu: Modern Educational Technology, Vo1.25 (2015) No.8, p.46. (In Chinese)

[2] X.G Li, S.L Jin and Y.W Wang: Distance Education in China, (2013) No.7, p.38. (In Chinese)

[3] H. Zhao, L. Chen and Y.T Zhao: Distance Education and Online Learning, Vo1.340 (2015) No.5, p.67. (In Chinese)

[4] Q. Wu and R.G Luo: Modern Distance Education, Vo1.151 (2014) No.1, p.55. (In Chinese)

[5] Q. Jiang, W. Zhao, H.X Liu and S. Li: Modern Distance Education Research, Vo1.138 (2015) No.6, p.105. (In Chinese) 
[6] Y.F Yang: Journal of Social Science of Harbin Normal University, Vo1. 30 (2015) No.5, p.9. (In Chinese)

[7] T.T Wang: The Design and Practice of Individualized Teaching Mode Based on Network Learning Behavior(MS., Liaoning Normal University, China 2016), p.8. (In Chinese)

[8] Q. Jiang, W. Zhao and P.J Wang: e-Education Research, Vol. 235 (2012) No.11, p.57. (In Chinese)

[9] Y. Ren, M.M Fei and W.T Gan: China Adult Education, (2017) No.13, p.96. (In Chinese)

[10]Z.J Wang, L. Chen, M. Chen and T.T Li: Distance Education in China, (2017) No.2, p.45. (In Chinese)

[11] Q.F Che and Y. Fang: The Chinese Journal of ICT in Education, (2017) No.2, p.43. (In Chinese)

[12]J. Bergman and A. Sam: Flipped classroom and MOOC education (Chinese Youth Press, China 2015). (In Chinese) 